\title{
O SERVIÇO DE PERÍCIA DE INCÊNDIOS E EXPLOSÕES NO ESTADO DO ESPÍRITO SANTO: UMA ANÁLISE DO PERÍODO DE 1989 a 1999
}

Carlos Marcelo D'lsep Costa ${ }^{1}$

\section{RESUMO}

O presente trabalho buscou analisar o serviço de perícia de incêndios e explosões no Estado do Espírito Santo no período de 1989 a 1999. O texto apresenta também uma breve retrospectiva histórica do serviço, além de esclarecer o papel exercido pelo Corpo de Bombeiros Militar do Estado do Espírito Santo (CBMES) a partir da Constituição Estadual de 1989. O levantamento dos dados foi realizado por meio da análise de 609 laudos periciais confeccionados nesse período. Como resultados, são apresentados os aspectos relacionados aos tipos de incêndios, suas causas e características, existência de seguro incêndio, número de vítimas relacionadas aos incêndios, distribuição por municípios, quantidade anual e o número de perícias realizadas. A pesquisa mostrou que de uma forma geral o serviço de perícia de incêndios e explosões no período analisado cumpriu bem as finalidades de elucidação das causas dos incêndios, auxílio às questões de justiça e respaldo às companhias de seguro. Entretanto, não apresentou dados que evidenciassem a retroalimentação do Ciclo Operacional de Bombeiros.

Palavras-Chave: Segurança pública. Organizações militares. Corpo de bombeiros militares. Perícia. Incêndios. Perícia de incêndios e explosões.

\footnotetext{
${ }^{1}$ Coronel BM Comandante-Geral do Corpo de Bombeiros Militar do Estado do Espírito Santo. Perito em Incêndios e Explosões. Mestre em Gestão Empresarial pela Fundação Getulio Vargas. marcelo.disep@bombeiros.es.gov.br
} 


\title{
THE SERVICE IN THE PERICIAL OF FIRE AND EXPLOSIONS IN THE STATES OF ESPÍRITO SANTO: ANALYSIS OF THE PERIOD 1989 TO 1999
}

\begin{abstract}
This paper seeks to analyze the fire and explosions investigation activity in the State of Espírito Santo-Brazil in the period from 1989 to 1999. The text also presents a brief historical retrospective of the activity, as well as clarify the role action by the Espírito Santo Military fire Corps (CBMES) from the State Constitution of 1989. The survey of data was accomplished through a thorough analysis of the 609 fire investigation reports of the period. The results lodge the aspects related to the types of fires, their causes and characteristics, existence of fire insurance, fire-related casualties, distribution by municipalities and annual quantity and the number of inspections carried out by fire investigators. The Research has shown that in general that the fires and explosions investigations activity in the analyzed period fulfilled the purposes of elucidation of the causes of the fires, aid to issues of Justice and backed by insurance companies. However, did not provide data showing the feedback of the Fire Service Operating Cycle.
\end{abstract}

Keywords: Public safety. Military Institutions. Military fire Corps. Fire Investigation.

\section{Artigo Recebido em 21/07/2017 e Aceito em 12/10/2017}

\section{INTRODUÇÃO}

Etimologicamente, a palavra perícia tem origem no latim peritia que, em sua essência, significa experiência adquirida, execução correta por meio do conhecimento, arte, habilidade. De igual maneira, a palavra 'perito' origina-se de peritus, que significa experimentado, que tem a experiência de, hábil em, versado, instruído (LOPES DE SÁ, 2011). 


\title{
Revista FLAMMAE
}

Revista Científica do Corpo de Bombeiros Militar de Pernambuco

Seção 1 - Artigos Técnico Científicos

Artigo publicado no Vol.03 N07 - Edição de JUL a DEZ 2017 - ISSN 2359-4829

Versão on-line disponível em: http://www.revistaflammae.com.

As definições apresentadas, considerando simplesmente a etimologia das palavras, são pouco precisas e tampouco sinalizam para um ramo do conhecimento técnico-científico que indique a habilidade necessária para o desenvolvimento do trabalho pericial.

$\mathrm{Na}$ realidade, a perícia pode ter várias naturezas dependendo de seu objeto de estudo. Ela pode ser criminal, de engenharia, ambiental, contábil, de medicina, de tecnologia, enfim, dos mais variados ramos em que o concurso do conhecimento técnico-científico se faça necessário. Assim, de acordo com a sua natureza, são apresentadas uma variedade de definições. Entretanto, de uma forma geral, pode-se definir que:

\begin{abstract}
Perícia é uma diligência realizada ou executada por peritos, a fim de esclarecer ou evidenciar certos fatos objeto do litígio judicial ou por interesse extrajudicial. Significa a investigação, o exame, a verificação da verdade ou realidade de certos fatos, por pessoas que tenham habilitação profissional, reconhecida experiência quanto à matéria e ilibada idoneidade moral. (SANTOS, 2006, p.16).
\end{abstract}

Desta forma, com base em Vasconcelos, Frabi e Castro (2011), a perícia pode ser entendida como uma atividade realizada por profissionais habilitados (peritos) com o propósito de elucidar determinados fatos. Ela tem a função de processar e interpretar os indícios e vestígios, sendo materializada em um laudo pericial, ou seja, em um documento formal.

Nesse contexto, e tendo como objeto de estudo os incêndios, encontramos outra natureza de perícia que é a de incêndios. Para Sarte (2009, p.29)

\footnotetext{
A Perícia de Incêndios é o estudo minucioso do local onde ocorreu o incêndio, pois nele encontram-se as informações necessárias para o seu esclarecimento. Consiste na análise dos vestígios observados e coletados nos locais onde ocorreu o sinistro, a fim de se concluir, com a formulação de documentação específica (Laudo Pericial), a causa, a origem, a propagação do fogo dentre outras informações pertinentes à elucidação da ocorrência.
} 
Assim, oficiais bombeiros militares com especialização em perícia de incêndios e explosões e dentro das atribuições legais dos Corpos de Bombeiros Militares realizam perícias de incêndios e explosões com as seguintes finalidades: elucidar a causa real do incêndio (caracterizando o seu desenvolvimento, as consequências, os danos e prejuízos); retroalimentar o Ciclo Operacional de Bombeiros ${ }^{2}$; e fornecer subsídios para a justiça ${ }^{3}$, indústria e companhias de seguros.

Por sua vez, para Aragão (2010, p. 66) "a perícia de incêndios é um ramo especialíssimo da perícia criminalística em matéria de engenharia" e, portanto, para realizá-la é necessário ser perito criminal. Essa linha é defendida pela grande maioria dos peritos criminalísticos brasileiros.

É justamente nesse aspecto que existe uma discussão sobre a competência legal para realização de tais perícias, pois hoje no Brasil, elas são realizadas em alguns Estados pelas Polícias Técnico-Científicas ou Institutos de Criminalística e, em outros, pelos Corpos de Bombeiros Militares, conforme disposto nas Constituições e legislações infraconstitucionais dos Estados da Federação.

${ }^{2}$ O Ciclo Operacional de Bombeiros compreende quatro fases bem distintas, cada uma apresentando finalidade específica, objeto de estudo, custeio da atividade, recursos humanos e recursos materiais peculiares. As quatro fases são: Fase Normativa ou Preventiva (finalidade de evitar a ocorrência do sinistro; analisar os riscos; estudar, revisar e elaborar normas de segurança); Fase Passiva ou Estrutural (finalidade de restringir, com prontidão, as consequências e os danos de um sinistro que não pôde ser evitado; instalar, inspecionar, fazer manutenção e operar sistemas e dispositivos de segurança contra incêndios; Fase Ativa ou de Combate (finalidade de extinguir incêndios, socorrer e salvar vidas e bens); e a Fase Investigativa ou Pericial (finalidade de elucidar o caso real de incêndio, em todas as suas circunstâncias: causa, desenvolvimento, consequências, danos e prejuízos, e fornecer subsídios para a retroalimentação das demais fases do ciclo operacional).

${ }^{3}$ A apuração de todas as circunstâncias que deram causa a um incêndio e o como ele se desenvolveu no local é indispensável porque, na verdade, são elas que sinalizam o cometimento de crimes tipificados no Código Penal (CP) brasileiro, pois o fogo pode caracterizar crime de dano (art. 163), de fraude para recebimento de indenização ou valor de seguro (art. $171, \S 2^{\circ}, \mathrm{V}$ ) ou ter causado perigo para a vida, a integridade física ou patrimônio de terceiros, podendo ser crime de incêndio doloso ou culposo (art. 250, caput ou $\S 2^{\circ}$ ). Igual tratamento deve ser dispensado quando uma explosão expuser a perigo a vida, a integridade física ou o patrimônio de terceiros, pois poderá caracterizar crime de explosão dolosa ou culposa (art. 251, caput ou $\S 3^{\circ}$ ). 


\section{Revista FLAMMAE}

Revista Científica do Corpo de Bombeiros Militar de Pernambuco

Seção 1 - Artigos Técnico Científicos

Artigo publicado no Vol.03 Nº7 - Edição de JUL a DEZ 2017 - ISSN 2359-4829

Versão on-line disponível em: http://www.revistaflammae.com.

Entretanto, à margem dessa discussão encontram-se os propósitos ou os objetivos básicos da perícia de incêndios, pois o Código de Processo Penal (CPP), em seu artigo 173, estabelece que os peritos, no caso de sinistro provocado pelo fogo, deverão verificar a causa e o lugar no qual o incêndio teve início.

Art. 173. No caso de incêndio, os peritos verificarão a causa e o lugar em que houver começado, o perigo que dele tiver resultado para a vida ou para o patrimônio alheio, a extensão do dano e o seu valor e as demais circunstâncias que interessarem à elucidação do fato. (BRASIL, 1941).

Deve-se registrar que este artigo não tem a intenção e nem o objetivo de suscitar a discussão sobre a competência para realização das perícias de incêndios. Na realidade, ele tem a finalidade básica de analisar o serviço de perícia de incêndios e explosões realizado pelo Corpo de Bombeiros Militar do Estado do Espírito Santo (CBMES) no período de 1989 a 1999, conforme previsto na Constituição do Estado do Espírito Santo de 1989.

A análise do serviço concentrou-se, notadamente, na pesquisa de documentos (Boletins do Comando do Corpo de Bombeiros, relatórios anuais do Corpo de Bombeiros, livros de registros de perícias de incêndios e ofícios expedidos no período da pesquisa) e na leitura dos laudos periciais para levantamento dos aspectos relacionados aos tipos de incêndios, suas causas e características, existência de seguro incêndio, número de vítimas associadas aos incêndios, distribuição por municípios, quantidade anual e o número de perícias realizadas por peritos. Os dados levantados foram dispostos em quadros para facilitar a sua apresentação.

Com o objetivo de contextualizar a análise, o texto apresenta também uma breve retrospectiva histórica do serviço de perícia de incêndios e explosões e o papel exercido pelo CBMES a partir da Constituição do Estado do Espírito Santo de 1989. 


\section{Revista FLAMMAE}

Revista Científica do Corpo de Bombeiros Militar de Pernambuco

Seção 1 - Artigos Técnico Científicos

Artigo publicado no Vol.03 Nº7 - Edição de JUL a DEZ 2017 - ISSN 2359-4829

Versão on-line disponível em: http://www.revistaflammae.com.

\section{Breve Retrospectiva Histórica do Serviço de Perícia de Incêndios e Explosões}

A retrospectiva histórica do Serviço de Perícia de Incêndios e Explosões no Estado do Espírito Santo tem como eixo central a análise da legislação estadual pertinente. Nesse sentido, verificou-se, inicialmente, que os assuntos referentes à Segurança Pública estavam previstos nos artigos 97 a 101 da Seção VIII do Capítulo V da Constituição do Estado do Espírito Santo de $1967^{4}$ e que não havia uma definição sobre a competência para a realização das perícias de incêndios.

\footnotetext{
Capítulo V - Do Poder Executivo(...)

Seção VIII - Da Segurança Pública
}

Art. 97 - (...)

Art. 98 - A Polícia Militar do Estado é uma instituição regular e permanente, organizada com base na hierarquia e disciplina, sob a autoridade do Governador do Estado, e dentro dos limites da lei, destina-se à garantia dos Poderes constituídos, da lei e da ordem.

Art. 99 - A Polícia Militar do Estado, bem como o Corpo de Bombeiros, que dela é parte integrante, são considerados forças auxiliares, reserva do Exercito, (...).

Art. $100-(\ldots)$

Art. 101 - A Polícia Civil destina-se com as atribuições fixadas em lei, a preservar a ordem pública, apurar as infrações penais ocorridas no território do estado e a cooperar com as autoridades federais e de outros Estados na repressão da criminalidade. (ESPÍRITO SANTO (Estado), 1984)

$\mathrm{Na}$ realidade, existiam dois dispositivos infraconstitucionais que atribuíam a competência para a realização das perícias de incêndios no

\footnotetext{
${ }^{4}$ Constituição do Estado do Espírito Santo, de 15 de maio de 1967, com a redação dada pela Emenda Constitucional $\mathrm{n}^{\circ} 1$, de 13 de novembro de 1971, e as alterações feitas pelas Emendas Constitucionais no 2, de 14 de julho de 1972 a 25, de 05 de junho de 1984.
} 


\section{Revista FLAMMAE}

Revista Científica do Corpo de Bombeiros Militar de Pernambuco

Seção 1 - Artigos Técnico Científicos

Artigo publicado no Vol.03 Nº7 - Edição de JUL a DEZ 2017 - ISSN 2359-4829

Versão on-line disponível em: http://www.revistaflammae.com.

território capixaba. O primeiro foi a Lei $\mathrm{n}^{\circ} 3.044 / 1975$ que estabelecia as missões e estrutura da Polícia Militar e o segundo foi o Decreto $n^{\circ} 2.089$ N/1985 que estabelecia o Quadro de Pessoal da Polícia Civil.

Na Polícia Militar do Estado do Espírito Santo (PMES), a Lei n 3.044, de 31 de dezembro de 1975, instituiu as missões, subordinação e organização básica. Na ocasião, o Corpo de Bombeiros era apenas um de seus órgãos de execução e apresentava a seguinte organização:

Art. 39 - O Corpo de Bombeiros da Polícia Militar será assim organizado:

- Comando;

- Centro de Suprimento e Manutenção de Material Operacional (CSM/Mop);

- Unidades Operacionais.

Art. 40 - O Comando compreenderá:

- O Comandante;

- O Estado Maior;

- A Secretaria; e

- A Seção de Comando.

$\S 1^{\circ}$ - Vetado.

$\S 2^{\circ}$ - O Estado-Maior será assim organizado:

- Chefe do Estado-Maior;

- $1^{\text {a }}$ Seção (B/1): pessoal;

- $2^{\mathrm{a}}$ Seção (B/2): informações;

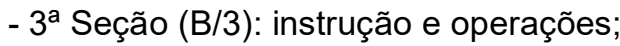

- $4^{a}$ Seção (B/4): fiscalização administrativa e logística;

- $5^{\mathrm{a}}$ Seção (B/5): assuntos civis; e

- 6a Seção (B/6): Seção de Serviços Técnicos incumbida de:

- executar e supervisionar o disposto na legislação do Estado quanto à instalação de equipamentos e às medidas preventivas contra incêndios;

- proceder a exames de plantas e a perícias; 


\section{Revista FLAMMAE}

Revista Científica do Corpo de Bombeiros Militar de Pernambuco

Seção 1 - Artigos Técnico Científicos

Artigo publicado no Vol.03 Nº7 - Edição de JUL a DEZ 2017 - ISSN 2359-4829

Versão on-line disponível em: http://www.revistaflammae.com.

- realizar testes de incombustibilidade;

- realizar vistorias e emitir pareceres;

- supervisionar a instalação da rede de hidrantes públicos.

(ESPÍRITO SANTO (Estado), 1975) (grifo do autor)

Observa-se que o termo 'perícias' aparece de forma genérica, sem estabelecer uma especificação do conhecimento técnico-científico. Entretanto, o Decreto $n^{\circ} 1.462$, de 10 de outubro de 1980, modificou a estrutura da PMES criando um órgão dentro do Corpo de Bombeiros com a competência para realização de perícias de incêndio. Esse fato, por meio de decreto, foi possível em virtude do que a Lei ${ }^{\circ} 3.044 / 75$ estabelecia em seu art. 56.

Art. 56 - Compete ao Governador do Estado, mediante decreto, a criação, transformação, extinção, denominação, localização e a estruturação dos Órgãos de Direção, dos Órgãos de Apoio e dos Órgãos de Execução da PM, de acordo com a organização básica prevista nesta Lei e dentro dos limites de efetivos fixados na Lei de Fixação de Efetivos, por proposta do Comandante Geral, após apreciação e aprovação do EME. (ESPÍRITO SANTO (Estado), 1975)

Desta forma, o art. 39 e o $\S 2^{\circ}$ do art. 40, da Lei $n^{\circ} 3.044$, de 31 de dezembro de 1975, passaram a vigorar com a seguinte redação:

Art. 39 - O Corpo de Bombeiros da Polícia Militar será assim organizado:

- Comando;

- Centro de Suprimento e Manutenção de Material Operacional (CSM/Mop);

- Centro de Atividades Técnicas;

- Unidades Operacionais.

Parágrafo Único - Compete ao Centro de Atividades Técnicas (CAT): 


\section{Revista FLAMMAE}

Revista Científica do Corpo de Bombeiros Militar de Pernambuco

Seção 1 - Artigos Técnico Científicos

Artigo publicado no Vol.03 Nº7 - Edição de JUL a DEZ 2017 - ISSN 2359-4829

Versão on-line disponível em: http://www.revistaflammae.com.

- executar e supervisionar o cumprimento das disposições

legais relativas às medidas de prevenção e proteção contra

incêndios;

- proceder a exames de plantas e de projetos de construção;

- realizar testes de incombustibilidade;

- realizar vistorias e emitir pareceres;

- supervisionar a instalação da rede de hidrantes públicos e privados.

- realizar as perícias de incêndio.

Art. $40-(\ldots)$

$\S 2^{\circ}$ - O Estado-Maior será assim organizado:

- Chefe do Estado-Maior;

- 1ª Seção (B/1): pessoal;

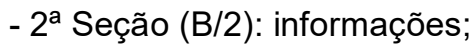

- $3^{\text {a }}$ Seção (B/3): instrução e operações;

- 4 ${ }^{\mathrm{a}}$ Seção (B/4): Assuntos administrativos;

- $5^{\mathrm{a}}$ Seção (B/5): assuntos civis. (ESPÍRITO SANTO (Estado), 1980) (grifo do autor)

Com essa modificação, tem-se a criação do Centro de Atividades

Técnicas (CAT) e a definição clara da natureza da perícia de competência do Corpo de Bombeiros.

Na Polícia Civil do Estado do Espírito Santo (PCES), o Decreto $\mathrm{n}^{\circ} 2.089-$ $\mathrm{N}$, de 10 de julho de 1985, estabelecia para o Quadro de Pessoal a seguinte classificação para os cargos efetivos: Cargos de Natureza Policial e Cargos de Natureza Técnico-Policial.

Nos Cargos de Natureza Técnico-Policial enquadravam-se as categorias de Perito Criminal Especial e Perito Criminal. Essas categorias possuíam as seguintes descrições sumárias e analíticas de suas atribuições, bem como, as qualificações necessárias: 


\section{Revista FLAMMAE}

Revista Científica do Corpo de Bombeiros Militar de Pernambuco

Seção 1 - Artigos Técnico Científicos

Artigo publicado no Vol.03 Nº7 - Edição de JUL a DEZ 2017 - ISSN 2359-4829

Versão on-line disponível em: http://www.revistaflammae.com.

\section{G - Perito Criminal Especial}

\section{Descrição Sumária das Atribuições}

Execução de trabalhos, compreendendo a realização de pericias, exames e pesquisa no setor de criminalística pura e no de especifica da química, física, engenharia, ciências contábeis, biologia, mineralogia ou geologia, bem como exames de pessoas vivas, cadáveres, peças anatômicas, em relação ao campo da odontologialegal.

\section{Descrição Analítica das Atribuições}

1 - Efetuar exames e pesquisas em locais de crime contra a vida, a incolumidade pública e ao patrimônio e em casos de delitos de transito;

(..)

12 - Efetuar pericias em locais de incêndios e explosões, recolhendo nesses locais materiais para posterior exame em laboratório, visando identificar substâncias inflamáveis ou explosivas; (..)

\section{Qualificação Necessária}

Ser portador de diploma de curso superior em uma das seguintes áreas: química, física, engenharia, ciências contábeis, biologia, odontologia, mineralogia ou geologia registrado no Conselho de Classe.

\section{$\mathrm{H}$ - Perito Criminal}

\section{Descrição Sumária das Atribuições}

Execução de estudos, pesquisa e perícias, visando ao esclarecimento e à prova das infrações penais, desabamentos,

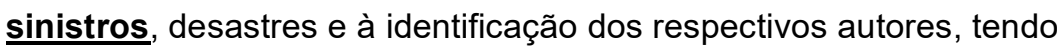
por objetivo os vestígios materiais extrínsecos, daquelas infrações. 


\section{Revista FLAMMAE}

Revista Científica do Corpo de Bombeiros Militar de Pernambuco

Seção 1 - Artigos Técnico Científicos

Artigo publicado no Vol.03 N07 - Edição de JUL a DEZ 2017 - ISSN 2359-4829

Versão on-line disponível em: http://www.revistaflammae.com.

Descrição Analítica das Atribuições

2 - Proceder a exames perícias, conforme a escala de plantão e a distribuição do serviço;

(...)

10 - Realizar outras perícias que se tornem necessárias, para a apuração do delito;

(...)

\section{Qualificação Necessária}

Ser portador de certificado de conclusão do $2^{\circ}$ Grau e Carteira Nacional de Habilitação. (ESPÍRITO SANTO (Estado), 1985) (grifo meu)

Com a promulgação da Constituição Estadual de 1989, as perícias em locais de incêndios e sinistros passam a ser missão constitucional da PMES, sendo consequentemente, realizadas pelo seu órgão específico, ou seja, o Corpo de Bombeiros.

Art. 130 - À Polícia Militar, instituição regular e permanente, organizada com base na hierarquia e disciplina, compete, com exclusividade, a polícia ostensiva, a preservação da ordem pública, a coordenação e a execução de ações de defesa civil, prevenção e combate a incêndios, perícias em locais de incêndios e sinistros, busca e salvamento, elaboração de normas relativas à segurança das pessoas e de seus bens contra incêndios e pânico, e outras previstas em lei. ${ }^{5}$ (grifo do autor)

Em virtude da nova atribuição constitucional, o Comando do Corpo de Bombeiros aprovou a primeira "Norma Reguladora para Realização de Perícias de Incêndios e Sinistros". Essa norma foi publicada no Boletim do Comando do Corpo de Bombeiros (BCCB) n 039, de 29 de maio de 1990, com a finalidade de orientar e conduzir os trabalhos de perícias de incêndios e sinistros, estabelecendo normas para a sua realização, controle e coordenação.

Assim, após a promulgação da Constituição Estadual de 1989, a competência para a realização das pericias de incêndios fica claramente

\footnotetext{
${ }^{5}$ Redação original do Art. 130 da Constituição do Estado do Espírito Santo de 1989.
} 


\section{Revista FLAMMAE}

Revista Científica do Corpo de Bombeiros Militar de Pernambuco

Seção 1 - Artigos Técnico Científicos

Artigo publicado no Vol.03 Nº7 - Edição de JUL a DEZ 2017 - ISSN 2359-4829

Versão on-line disponível em: http://www.revistaflammae.com.

definida e estabelecida no território capixaba, pois antes elas eram realizadas pelo Corpo de Bombeiros e pela Polícia Civil.

Em relação ao Corpo de Bombeiros, durante a pesquisa, foram encontradas arquivadas no Centro de Atividades Técnicas do CBMES 85 perícias de incêndios realizadas antes da promulgação da Constituição Estadual de 1989, sendo as primeiras realizadas no ano de 1973. A distribuição ao longo dos anos e o quantitativo dessas perícias estão apresentadas no Quadro 1.

Quadro 1 - Perícias de Incêndios Realizadas pelo Corpo de Bombeiros antes da Promulgação da Constituição Estadual de 1989.

\begin{tabular}{|c|c|c|c|}
\hline Ano & Qtd & Ano & Qtd \\
\hline 1973 & 04 & 1982 & 00 \\
\hline 1974 & 11 & 1983 & 00 \\
\hline 1975 & 08 & 1984 & 01 \\
\hline 1976 & 10 & 1985 & 01 \\
\hline 1977 & 05 & 1986 & 00 \\
\hline 1978 & 05 & 1987 & 14 \\
\hline 1979 & 02 & 1988 & 16 \\
\hline 1980 & 01 & 1989 & 05 \\
\hline 1981 & 02 & \\
\hline \multicolumn{4}{|c|}{ Total = 85 } \\
\hline
\end{tabular}

Fonte: Arquivos CBMES, organizado pelo autor.

Um aspecto interessante dessas perícias está na forma de registro dos primeiros trabalhos periciais. Eles eram manuscritos em um livro de registro de perícias (livro de capa dura, contendo termo de abertura e páginas numeradas) e não possuíam fotografias do local sinistrado. Somente a partir do ano de 1977 que elas passaram a ser registradas em um Laudo Pericial estruturado contendo um Laudo Fotográfico complementar. 


\section{Revista FLAMMAE}

Revista Científica do Corpo de Bombeiros Militar de Pernambuco

Seção 1 - Artigos Técnico Científicos

Artigo publicado no Vol.03 N07 - Edição de JUL a DEZ 2017 - ISSN 2359-4829

Versão on-line disponível em: http://www.revistaflammae.com.

No ano de 1989, foram realizadas mais duas perícias de incêndios, porém já como missão constitucional da Polícia Militar. Por esta razão, elas serão analisadas e computadas no período compreendido pelo estudo.

Entretanto, antes da apresentação da análise objeto do estudo, serão abordados os aspectos envolvendo a formação inicial do Corpo de Peritos e a alteração na Constituição Estadual que proporcionou a desvinculação do Corpo de Bombeiros da PMES.

O desenvolvimento do serviço de perícias de incêndios e explosões no Corpo de Bombeiros teve como componente primordial e fundamental, ao longo dos anos, a formação de um Corpo de Peritos. Na realidade, ela teve início bem antes dessa atividade ser considerada uma missão constitucional da PMES, pois no ano de 1976 foi enviado, pela primeira vez, um oficial para frequentar o Curso de Perícia de Incêndio do Corpo de Bombeiros Militar do Distrito Federal (CBMDF) ${ }^{6}$. Essa prática foi intensificada nos anos 80 e 90.

Entretanto, deve-se destacar e registrar o importante papel exercido pelos Oficiais PM que serviram no Corpo de Bombeiros (CBom) na década de $1970^{7}$. Foram eles que de forma pioneira conduziram os primeiros passos desse serviço. Mesmo sem possuírem uma formação específica, realizaram diversas perícias.

O Quadro 2 apresenta a relação nominal dos Oficias Peritos formados no Distrito Federal e o ano de realização do curso. Dentro das possibilidades,

6 Segundo Oliveira (2009) o primeiro Curso de Perícia de Incêndio para os Oficiais do CBMDF foi ministrado pelo Instituto Nacional de Criminalística da Polícia Federal por meio do Prof. Dr. Antônio Carlos Vila Nova no ano de 1973. [Processo $n^{\circ}$ 070005, Processo n. ${ }^{\circ} 173.951-73$ (16jul73) e D.O no 123 (14ago73)]. No mesmo ano, o Decreto $n^{\circ} 2.325$, de 17/07/73, atribuiu ao CBMDF a competência legal para realizar perícias de incêndios e explosões no âmbito do Distrito Federal.

7 Luiz Guilherme Paterlini; José Julio de Abreu; Argemiro dos Santos Brandão; Antônio Placidino Grégio; Heitor Bimbato; Ademar Poltronieri; Ewayr Martins Costa; Ernani de Siqueira Pádua Filho; Pio Jorge Pedrini; Marcos Antônio Santos, Carlos Magno da Paz Nogueira; Carlindo Tristão Charpinel; Olavo Gomes Bossoes; Luiz Carlos Dames de Miranda; Erli dos Santos; Asdrubal Wandelino Bremenkamp, Jair Cruz do Nascimento e Leônidas da Cunha. (Fonte: Laudos Periciais arquivados no CBMES) 


\section{Revista FLAMMAE}

Revista Científica do Corpo de Bombeiros Militar de Pernambuco

Seção 1 - Artigos Técnico Científicos

Artigo publicado no Vol.03 Nº7 - Edição de JUL a DEZ 2017 - ISSN 2359-4829

Versão on-line disponível em: http://www.revistaflammae.com.

uma medida de ordem prática adotada foi a de sempre encaminhar os oficiais em duplas para frequentarem o curso, pois invariavelmente eles passariam a atuar juntos na realização das perícias de incêndios e explosões.

\section{Quadro 2 - Oficiais Peritos Formados no CBMDF.}

\begin{tabular}{|c|c|}
\hline Peritos & $\begin{array}{c}\text { Ano do } \\
\text { Curso de Perícia }\end{array}$ \\
\hline Cap Ewayr Martins Costa & 1976 \\
\hline $1^{\circ}$ Ten Carlos Roberto Pádua & 1980 \\
\hline $1^{\circ}$ Ten Gabriel Cunha Amorim & 1980 \\
\hline $2^{\circ}$ Ten Paulo Roberto Moraes & 1983 \\
\hline $2^{\circ}$ Ten Aldoete Guede Sant'Ana & 1983 \\
\hline Cap José Antonio Caliman & 1984 \\
\hline Cap Hélio Soares da Luz Sodré & 1985 \\
\hline Cap Élvio Silva Rebouças & 1986 \\
\hline $2^{\circ}$ Ten Álvaro Coelho Duarte & 1987 \\
\hline $1^{\circ}$ Ten Jonacy Firme dos Santos & 1990 \\
\hline $1^{\circ}$ Ten Renato Luiz de Oliveira & 1993 \\
\hline $1^{\circ}$ Ten Carlos Marcelo D'Isep Costa & 1994 \\
\hline $1^{\circ}$ Ten Fabiano Marchetti Bonno & 1994 \\
\hline $1^{\circ}$ Ten João Antônio Daroz & 1995 \\
\hline $1^{\circ}$ Ten Paulo César Corrêa Lima & 1995 \\
\hline $1^{\circ}$ Ten Edvaldo Souza da Silva & 1996 \\
\hline $1^{\circ}$ Ten Samuel Rodrigues Barboza & 1997 \\
\hline $1^{\circ}$ Ten Gabriel Lopes & 1997 \\
\hline $2^{\circ}$ Ten Roger Vieira do Amaral & 1998 \\
\hline $1^{\circ}$ Ten André Có Silva & 1999 \\
\hline $2^{\circ}$ Ten Scharlyston Martins de Paiva & 1999 \\
\hline
\end{tabular}

Fonte: Diretoria de Investigação de Incêndio do CBMDF. 


\section{Revista FLAMMAE}

Revista Científica do Corpo de Bombeiros Militar de Pernambuco

Seção 1 - Artigos Técnico Científicos

Artigo publicado no Vol.03 Nº7 - Edição de JUL a DEZ 2017 - ISSN 2359-4829

Versão on-line disponível em: http://www.revistaflammae.com.

Em 1997, por meio da Emenda Constitucional n 12, o Corpo de Bombeiros deixou de ser um órgão de execução da PMES tornando-se uma organização autônoma e independente. Com o processo de desvinculação o Corpo de Bombeiros Militar do Estado do Espírito Santo (CBMES) passou a ser mais uma Corporação Militar do Estado com atribuições constitucionais claramente definidas.

Art. 130 - À Polícia Militar compete, com exclusividade, a polícia ostensiva e a preservação da ordem pública, e, ao Corpo de Bombeiros Militar, a coordenação e execução de ações de defesa civil, prevenção e combate a incêndios, perícias de incêndios e explosões em local de sinistros, busca e salvamento, elaboração de normas relativas à segurança das pessoas e de seus bens contra incêndios e pânico e outras previstas em lei. ${ }^{8}$ (grifo meu)

Na nova redação do art. 130 da Constituição Estadual, dois importantes aspectos podem ser destacados em relação à atividade de perícia de incêndios:

$\left.1^{\circ}\right)$ a ratificação da competência para realização das perícias de incêndios; e

$\left.2^{\circ}\right)$ a definição clara e objetiva de que a natureza da perícia realizada pelo Corpo de Bombeiros Militar é a perícia de incêndios e explosões ${ }^{9}$.

\footnotetext{
8 Art. 130 da Constituição do Estado do Espírito Santo de 1989 alterado pela Emenda Constitucional $n^{\circ} 12$, de 20 de agosto de 1997.

${ }^{9}$ Registra-se que em relação a explosões, as perícias são realizadas somente nas causadas por processos químicos, ou seja, as resultantes da combustão rápida ou decomposição violenta de uma substância com grande elevação de temperatura. As explosões causadas por processos físicos (aumento de pressão de um gás ou vapor em caldeiras, tubulações, cilindros, tambores de líquidos ou gases) são de pouco interesse para os casos de sinistroincêndio, uma vez que geralmente resultam no rompimento ou explosão do continente considerado, e portanto, não são objeto da perícia da Corporação.
} 


\section{Revista FLAMMAE}

Revista Científica do Corpo de Bombeiros Militar de Pernambuco

Seção 1 - Artigos Técnico Científicos

Artigo publicado no Vol.03 N07 - Edição de JUL a DEZ 2017 - ISSN 2359-4829

Versão on-line disponível em: http://www.revistaflammae.com.

Em decorrência da alteração da Constituição Estadual foi necessária a aprovação de um conjunto de dispositivos infraconstitucionais para consolidar o processo de desvinculação. O principal deles foi a Lei Complementar $\mathrm{n}^{\circ} 101$, de 22 de setembro de 1997, que dispõe sobre a organização básica do CBMES e dá outras providências.

A LC $n^{\circ}$ 101/197, em seu art. $2^{\circ}$, reforça a missão constitucional da Corporação e no art. 19 estabelece que o Centro de Atividades Técnicas (CAT) é o órgão responsável, dentro da estrutura do CBMES, para realizar as perícias de incêndios e explosões no Estado do Espírito Santo.

Art. $2^{\circ}$ Compete ao Corpo de Bombeiros Militar a coordenação e a execução de ações de defesa civil, prevenção e combate a incêndio, perícias de incêndios e explosões em locais de sinistros, busca e salvamento, elaboração de normas relativas à segurança das pessoas e dos seus bens contra incêndios e pânico e outras previstas em lei, no Estado do Espírito Santo.

(...)

Art. 19. O Centro de Atividades Técnicas (CAT), órgão subordinado diretamente ao Comando do Corpo de Bombeiros, tem como competência: estudar, analisar, planejar, normatizar, exigir e fiscalizar o cumprimento das disposições legais, assim como todos os serviços de segurança contra incêndio e pânico, bem como realizar perícias de incêndios e explosões em locais de sinistro no Estado do Espírito Santo. (Espírito Santo (Estado), 1997) (grifo meu)

Por sua vez, dentro da estrutura organizacional do CAT, a responsabilidade de coordenar e controlar todos os trabalhos de perícias de incêndios e explosões está a cargo da Seção de Perícias de Incêndio (SPI).

Diante do novo contexto e da nova realidade após o processo de emancipação da PMES, o CBMES, seguindo uma política de qualificação de pessoal, cria no ano de 2000 o seu próprio Curso de Perícia de Incêndios e Explosões (CPIE) ${ }^{10}$. O Curso visa o aprimoramento técnico-profissional de seus

${ }^{10}$ Após a criação já foram realizados dois cursos. O primeiro no próprio ano de 2000 e o segundo no ano de 2003. No CPIE/2000 foram formados 17 peritos e no CPIE/2003 mais 22 peritos. Este último, em virtude de uma parceria realizada com o Centro Universitário Vila Velha, foi realizado como Curso de Pós-Graduação Lato Sensu em Perícia de Incêndios e 


\section{Revista FLAMMAE}

Revista Científica do Corpo de Bombeiros Militar de Pernambuco

Seção 1 - Artigos Técnico Científicos

Artigo publicado no Vol.03 Nº7 - Edição de JUL a DEZ 2017 - ISSN 2359-4829

Versão on-line disponível em: http://www.revistaflammae.com.

oficiais, com a consequente renovação e atualização do Corpo de Peritos, além de atender à crescente demanda do serviço de perícia de incêndios e explosões.

Após a breve retrospectiva histórica do serviço de perícia de incêndios e explosões no Estado do Espírito Santo e a contextualização do papel exercido pelo CBMES a partir da Constituição Estadual de 1989, no próximo tópico serão apresentados os resultados da pesquisa sobre esse serviço no período de 1989 a 1999.

\section{O Serviço de Perícia de Incêndios e Explosões no Período de 1989 a 1999}

Por falta de um registro sistematizado dos laudos periciais e de um controle estatístico confiável por parte da Seção de Perícias de Incêndio do CAT (SPI), sobretudo, do período de 1989 a 1999, o autor, juntamente com um auxiliar de perícia, realizou durante os meses de fevereiro e março de 2012 uma pesquisa e coleta de dados em cada um dos 609 laudos confeccionados nesse período.

Todos os laudos possuem cópias xerográficas que estão arquivadas na $\mathrm{SPI}^{11}$. Elas estão armazenadas em caixas para arquivo e divididas por ano. Para cada ano, encontram-se registrados nas caixas apenas o total de perícias e a relação com a numeração dos laudos periciais.

Dessa forma, após a definição preliminar dos aspectos importantes para a análise do serviço de perícia de incêndios e explosões no período de 1989 a 1999, foi necessária a leitura de cada um dos laudos para a coleta dos dados. Ela se concentrou nos aspectos relativos à quantidade anual de perícias;

Explosões (aprovado pela Resolução $n^{\circ} 008$, de 13/02/2003 do CONSU, tendo cumprido as disposições da Resolução CNE/CES n 01/2001). Encontra-se em fase de estudo no CBMES a realização do terceiro CPIE (pós-graduação lato sensu) no ano de 2017.

${ }^{11} \mathrm{O}$ arquivamento da cópia dos laudos periciais é um procedimento de controle previsto na Norma Reguladora para a Realização de Perícias de Incêndios e Explosões do CBMES. 


\section{Revista FLAMMAE}

Revista Científica do Corpo de Bombeiros Militar de Pernambuco

Seção 1 - Artigos Técnico Científicos

Artigo publicado no Vol.03 Nº7 - Edição de JUL a DEZ 2017 - ISSN 2359-4829

Versão on-line disponível em: http://www.revistaflammae.com.

distribuição por município; tipo de incêndio; causa e característica do incêndio; existência ou não de seguro incêndio; número de vítimas relacionadas aos incêndios e número de perícias realizadas por peritos.

Inicialmente os dados de cada ano foram reunidos em planilhas criadas no programa Microsoft Excel. Após o lançamento dos dados de todos os anos e uma análise preliminar, eles foram reunidos em planilhas gerais para cada um dos aspectos levantados e os resultados transportados para os quadros apresentados neste artigo.

\subsection{Número de Perícias}

O serviço de perícia de incêndios e explosões no período de 1989 a 1999 era realizado no regime de escala de 24 horas com dois peritos de serviço diariamente. Concorriam à escala de perito todos os tenentes, capitães e majores peritos, sendo escalados como $1^{\circ}$ ou $2^{\circ}$ Peritos.

O acionamento dos peritos era realizado pelo Oficial Chefe de Operações, por meio do Centro de Operações de Bombeiros (COBOM), obedecendo ao previsto na Norma Reguladora para a Realização de Perícias de Incêndios e Explosões do CBMES.

As perícias eram realizadas pelas duplas de peritos, ficando $01^{\circ}$ Perito com a responsabilidade de confecção e entrega do laudo pericial. O Quadro 3 apresenta o número de perícias realizadas pelos peritos que atuaram no período, a discriminação do ano de realização do Curso de Perícia de Incêndio e as atuações como $1^{\circ}$ e $2^{\circ}$ perito. 


\section{Revista FLAMMAE}

Revista Científica do Corpo de Bombeiros Militar de Pernambuco

Seção 1 - Artigos Técnico Científicos

Artigo publicado no Vol.03 Nº7 - Edição de JUL a DEZ 2017 - ISSN 2359-4829

Versão on-line disponível em: http://www.revistaflammae.com.

Quadro 3 - Número de Perícias Realizadas por Peritos.

\begin{tabular}{|c|c|c|c|c|}
\hline Peritos & $\begin{array}{c}\text { Ano do } \\
\text { Curso de Perícia }\end{array}$ & $\begin{array}{l}\text { Atuação } \\
\text { 1 Perito }\end{array}$ & $\begin{array}{l}\text { Atuação } \\
\text { 20 Perito }\end{array}$ & $\begin{array}{c}\text { Número de } \\
\text { Perícias }\end{array}$ \\
\hline Gabriel Cunha Amorim & 1980 & 08 & 04 & 12 \\
\hline Paulo Roberto Moraes & 1983 & 05 & 18 & 23 \\
\hline Aldoete Guede Sant'Ana & 1983 & 08 & 02 & 10 \\
\hline Hélio Soares da Luz Sodré & 1985 & 08 & 01 & 09 \\
\hline Élvio Silva Rebouças & 1986 & 102 & 30 & 132 \\
\hline Álvaro Coelho Duarte & 1987 & 45 & 59 & 104 \\
\hline Jonacy Firme dos Santos & 1990 & 74 & 82 & 156 \\
\hline Renato Luiz de Oliveira & 1993 & 26 & 16 & 42 \\
\hline Carlos Marcelo D'Isep Costa & 1994 & 63 & 92 & 155 \\
\hline Fabiano Marchetti Bonno & 1994 & 36 & 71 & 107 \\
\hline João Antônio Daroz & 1995 & 09 & 04 & 13 \\
\hline Paulo César Corrêa Lima & 1995 & 55 & 38 & 93 \\
\hline Edvaldo Souza da Silva & 1996 & 42 & 39 & 91 \\
\hline Samuel Rodrigues Barboza & 1997 & 31 & 38 & 69 \\
\hline Gabriel Lopes & 1997 & 54 & 52 & 106 \\
\hline Roger Vieira do Amaral & 1998 & 32 & 25 & 57 \\
\hline André Có Silva & 1999 & 06 & 10 & 16 \\
\hline Scharlyston Martins de Paiva & 1999 & 05 & 09 & 14 \\
\hline
\end{tabular}

Fonte: Arquivos CBMES, organizado pelo autor.

Dos 609 laudos confeccionados observou-se que em 19 deles $02^{\circ}$ Perito era um oficial do Corpo de Bombeiros que não possuía o curso de perícia de incêndio, sendo designado conforme previsto no art. 159 do Código de Processo Penal ${ }^{12}$. Essas exceções ocorreram nos anos de 1990, 1991 e

${ }^{12}$ Decreto-Lei ${ }^{\circ}$ 3.689, de 3 de outubro de 1941. 


\section{Revista FLAMMAE}

Revista Científica do Corpo de Bombeiros Militar de Pernambuco

Seção 1 - Artigos Técnico Científicos

Artigo publicado no Vol.03 N07 - Edição de JUL a DEZ 2017 - ISSN 2359-4829

Versão on-line disponível em: http://www.revistaflammae.com.

1992, sobretudo, pelo reduzido número de oficiais peritos que se encontravam servindo no Corpo de Bombeiros da PMES.

\subsection{Quantidade Anual de Perícias}

Observa-se, logo no primeiro ano de vigência da Constituição Estadual de 1989, um aumento significativo no número de perícias realizadas pelo Corpo de Bombeiros. O Quadro 4 apresenta a quantidade anual de perícias realizadas e a sua distribuição mensal em cada ano.

Quadro 4 - Quantidade Anual de Perícias.

\begin{tabular}{|l|c|c|c|c|c|c|c|c|c|c|c|c|}
\hline \multicolumn{1}{|c|}{ Mês } & $\mathbf{1 9 8 9}$ & $\mathbf{1 9 9 0}$ & $\mathbf{1 9 9 1}$ & $\mathbf{1 9 9 2}$ & $\mathbf{1 9 9 3}$ & $\mathbf{1 9 9 4}$ & $\mathbf{1 9 9 5}$ & $\mathbf{1 9 9 6}$ & $\mathbf{1 9 9 7}$ & $\mathbf{1 9 9 8}$ & $\mathbf{1 9 9 9}$ & Total \\
\hline Janeiro & & 00 & 03 & 00 & 06 & 03 & 06 & 08 & 06 & 05 & 10 & $\mathbf{4 7}$ \\
\hline Fevereiro & & 04 & 04 & 05 & 03 & 03 & 05 & 01 & 08 & 08 & 14 & $\mathbf{5 5}$ \\
\hline Março & & 04 & 03 & 03 & 11 & 04 & 06 & 02 & 07 & 08 & 07 & $\mathbf{5 5}$ \\
\hline Abril & & 02 & 02 & 04 & 03 & 04 & 04 & 03 & 04 & 14 & 06 & $\mathbf{4 6}$ \\
\hline Maio & & 00 & 14 & 02 & 01 & 04 & 06 & 07 & 04 & 08 & 04 & $\mathbf{5 0}$ \\
\hline Junho & & 00 & 04 & 05 & 05 & 04 & 07 & 02 & 05 & 06 & 07 & $\mathbf{4 5}$ \\
\hline Julho & & 01 & 04 & 02 & 07 & 04 & 04 & 04 & 15 & 09 & 09 & $\mathbf{5 9}$ \\
\hline Agosto & & 03 & 01 & 06 & 07 & 02 & 05 & 04 & 08 & 12 & 05 & $\mathbf{5 3}$ \\
\hline Setembro & & 11 & 02 & 03 & 01 & 03 & 05 & 03 & 08 & 04 & 12 & $\mathbf{5 2}$ \\
\hline Outubro & 01 & 05 & 04 & 07 & 03 & 03 & 04 & 04 & 05 & 05 & 08 & $\mathbf{4 9}$ \\
\hline Novembro & 01 & 06 & 01 & 04 & 05 & 06 & 03 & 08 & 09 & 01 & 02 & $\mathbf{4 6}$ \\
\hline Dezembro & 00 & 03 & 05 & 05 & 03 & 04 & 02 & 06 & 10 & 04 & 10 & $\mathbf{5 2}$ \\
\hline \multicolumn{1}{|c|}{ Total } & $\mathbf{0 2}$ & $\mathbf{3 9}$ & $\mathbf{4 7}$ & $\mathbf{4 6}$ & $\mathbf{5 5}$ & $\mathbf{4 4}$ & $\mathbf{5 7}$ & $\mathbf{5 2}$ & $\mathbf{8 9}$ & $\mathbf{8 4}$ & $\mathbf{9 4}$ & $\mathbf{6 0 9}$ \\
\hline
\end{tabular}

Fonte: Arquivos CBMES, organizado pelo autor.

Não foi possível, em decorrência da escassez de dados, realizar uma avaliação e uma comparação entre o número de incêndios atendidos anualmente pela Corporação e o número de perícias de incêndios e explosões realizadas no período da pesquisa. 


\section{Revista FLAMMAE}

Revista Científica do Corpo de Bombeiros Militar de Pernambuco

Seção 1 - Artigos Técnico Científicos

Artigo publicado no Vol.03 Nº7 - Edição de JUL a DEZ 2017 - ISSN 2359-4829

Versão on-line disponível em: http://www.revistaflammae.com.

\subsection{Distribuição das Perícias por Municípios}

Dos 78 municípios existentes no estado, as 609 perícias de incêndios foram realizadas em 39 deles, conforme a distribuição apresentada no Quadro 5. Verifica-se que do total, 496 perícias $(81,44 \%)$ se concentram em 06 municípios da Região Metropolitana da Grande Vitória (RMGV) ${ }^{13}$, da seguinte maneira: Vitória (172), Vila Velha (120), Serra (91), Cariacica (77), Guarapari (24) e Viana (12).

Esse fato pode ser explicado em razão dos municípios da RMGV abrigarem, segundo dados do IBGE/2010, 46\% da população total do Estado do Espírito Santo e $57 \%$ da sua população urbana, além de produzirem $58 \%$ da riqueza e consumirem $55 \%$ da energia elétrica, ou seja, é onde existe naturalmente a maior pressão e demanda pelos serviços públicos.

Dentro da distribuição apresentada, observa-se ainda que 62 (10,18\%) das perícias de incêndios foram realizadas nos grandes municípios do interior do Estado: Cachoeiro de Itapemirim (23), São Mateus (20), Linhares (13) e Colatina (6); ficando as 51 restantes $(8,40 \%)$ distribuídas nos demais 29 municípios.

Quadro 5 - Distribuição das Perícias por Municípios.

\begin{tabular}{|l|c|c|c|c|c|c|c|c|c|c|c|c|}
\hline \multicolumn{1}{|c|}{ Município } & $\mathbf{1 9 8 9}$ & $\mathbf{1 9 9 0}$ & $\mathbf{1 9 9 1}$ & $\mathbf{1 9 9 2}$ & $\mathbf{1 9 9 3}$ & $\mathbf{1 9 9 4}$ & $\mathbf{1 9 9 5}$ & $\mathbf{1 9 9 6}$ & $\mathbf{1 9 9 7}$ & $\mathbf{1 9 9 8}$ & $\mathbf{1 9 9 9}$ & Total \\
\hline Afonso Claudio & 00 & 00 & 00 & 00 & 00 & 00 & 01 & 01 & 00 & 00 & 00 & $\mathbf{0 2}$ \\
\hline Anchieta & 00 & 01 & 00 & 00 & 00 & 01 & 00 & 00 & 00 & 00 & 00 & $\mathbf{0 2}$ \\
\hline Aracruz & 00 & 00 & 00 & 00 & 00 & 00 & 00 & 02 & 00 & 01 & 00 & $\mathbf{0 3}$ \\
\hline Baixo Guandu & 00 & 00 & 00 & 00 & 00 & 00 & 00 & 01 & 00 & 00 & 00 & $\mathbf{0 1}$ \\
\hline Barra de São Francisco & 00 & 00 & 00 & 00 & 00 & 00 & 00 & 00 & 00 & 02 & 00 & $\mathbf{0 2}$ \\
\hline Cachoeiro de Itapemirim & 00 & 03 & 03 & 01 & 02 & 01 & 05 & 02 & 02 & 02 & 02 & $\mathbf{2 3}$ \\
\hline Cariacica & 01 & 06 & 06 & 07 & 08 & 06 & 10 & 01 & 09 & 13 & 10 & $\mathbf{7 7}$ \\
\hline Colatina & 00 & 01 & 00 & 00 & 00 & 00 & 01 & 01 & 01 & 00 & 02 & $\mathbf{0 6}$ \\
\hline
\end{tabular}

13 A Região Metropolitana da Grande Vitória é formada pelos municípios de Cariacica, Fundão, Guarapari, Serra, Viana, Vila Velha e Vitória. Ela foi instituída pela Lei Complementar n 58, de 21 de fevereiro de 1995. 


\section{Revista FLAMMAE}

Revista Científica do Corpo de Bombeiros Militar de Pernambuco

Seção 1 - Artigos Técnico Científicos

Artigo publicado no Vol.03 Nº7 - Edição de JUL a DEZ 2017 - ISSN 2359-4829

Versão on-line disponível em: http://www.revistaflammae.com.

\begin{tabular}{|c|c|c|c|c|c|c|c|c|c|c|c|c|}
\hline Conceição da Barra & 00 & 00 & 00 & 00 & 00 & 00 & 00 & 00 & 01 & 01 & 01 & 03 \\
\hline Domingos Martins & 00 & 00 & 00 & 00 & 00 & 00 & 00 & 00 & 00 & 01 & 00 & 01 \\
\hline Fundão & 00 & 00 & 00 & 00 & 00 & 00 & 00 & 00 & 01 & 00 & 00 & 01 \\
\hline Guarapari & 00 & 03 & 01 & 00 & 01 & 00 & 01 & 04 & 01 & 05 & 08 & 24 \\
\hline Ibiraçu & 00 & 00 & 00 & 00 & 00 & 00 & 00 & 01 & 00 & 01 & 01 & 03 \\
\hline Itapemirim & 00 & 00 & 00 & 00 & 00 & 01 & 00 & 00 & 00 & 00 & 00 & 01 \\
\hline Itarana & 00 & 00 & 00 & 00 & 00 & 00 & 01 & 00 & 00 & 00 & 00 & 01 \\
\hline Ibitirama & 00 & 00 & 00 & 00 & 00 & 00 & 00 & 00 & 00 & 00 & 01 & 01 \\
\hline Itaguaçu & 00 & 00 & 00 & 00 & 00 & 00 & 00 & 00 & 00 & 00 & 01 & 01 \\
\hline João Neiva & 00 & 00 & 01 & 00 & 00 & 00 & 00 & 00 & 00 & 00 & 00 & 01 \\
\hline Linhares & 00 & 00 & 00 & 00 & 03 & 01 & 02 & 00 & 01 & 06 & 00 & 13 \\
\hline Marilândia & 00 & 01 & 00 & 00 & 00 & 00 & 00 & 00 & 00 & 00 & 00 & 01 \\
\hline Montanha & 00 & 00 & 00 & 00 & 01 & 01 & 00 & 00 & 01 & 00 & 00 & 03 \\
\hline Nova Venécia & 00 & 00 & 00 & 00 & 00 & 00 & 00 & 00 & 01 & 00 & 00 & 01 \\
\hline Pancas & 00 & 00 & 00 & 00 & 01 & 00 & 00 & 00 & 00 & 00 & 00 & 01 \\
\hline Pedro Canário & 00 & 00 & 00 & 00 & 01 & 00 & 00 & 00 & 00 & 02 & 00 & 03 \\
\hline Pinheiros & 00 & 00 & 00 & 00 & 00 & 00 & 00 & 00 & 01 & 00 & 00 & 01 \\
\hline Piúma & 00 & 00 & 00 & 00 & 01 & 01 & 00 & 00 & 00 & 00 & 01 & 03 \\
\hline Rio Bananal & 00 & 00 & 00 & 01 & 00 & 00 & 00 & 00 & 00 & 00 & 00 & 01 \\
\hline Santa Leopoldina & 00 & 00 & 00 & 00 & 00 & 00 & 00 & 01 & 00 & 01 & 00 & 02 \\
\hline Santa Tereza & 00 & 00 & 00 & 01 & 00 & 00 & 00 & 00 & 02 & 00 & 01 & 04 \\
\hline São Domingos do Norte & 00 & 00 & 00 & 00 & 00 & 00 & 00 & 00 & 00 & 01 & 00 & 01 \\
\hline São Gabriel da Palha & 00 & 00 & 00 & 01 & 00 & 00 & 00 & 01 & 01 & 01 & 00 & 04 \\
\hline São José do Calçado & 00 & 00 & 00 & 00 & 00 & 01 & 00 & 00 & 00 & 00 & 00 & 01 \\
\hline São Mateus & 00 & 01 & 00 & 00 & 00 & 01 & 00 & 00 & 10 & 02 & 06 & 20 \\
\hline Serra & 00 & 07 & 07 & 07 & 09 & 06 & 09 & 06 & 11 & 11 & 18 & 91 \\
\hline Vargem Alta & 00 & 00 & 00 & 00 & 00 & 00 & 00 & 01 & 00 & 00 & 00 & 01 \\
\hline Viana & 00 & 01 & 04 & 01 & 00 & 00 & 02 & 00 & 02 & 01 & 01 & 12 \\
\hline Vila Valério & 00 & 00 & 00 & 00 & 00 & 00 & 00 & 00 & 00 & 01 & 00 & 01 \\
\hline Vila Velha & 00 & 05 & 10 & 14 & 14 & 07 & 12 & 11 & 22 & 11 & 14 & 120 \\
\hline Vitória & 01 & 10 & 15 & 13 & 14 & 17 & 13 & 19 & 22 & 21 & 27 & 172 \\
\hline Total & 02 & 39 & 47 & 46 & 55 & 44 & 57 & 52 & 89 & 84 & 94 & 609 \\
\hline
\end{tabular}

Fonte: Arquivos CBMES, organizado pelo autor.. 


\section{Revista FLAMMAE}

Revista Científica do Corpo de Bombeiros Militar de Pernambuco

Seção 1 - Artigos Técnico Científicos

Artigo publicado no Vol.03 Nº7 - Edição de JUL a DEZ 2017 - ISSN 2359-4829

Versão on-line disponível em: http://www.revistaflammae.com.

\subsection{Tipo de Incêndio}

Para o Serviço de Perícia de Incêndio e Explosões o tipo de incêndio está associado às características construtivas do local em que ocorreu o sinistro. Os tipos utilizados no período analisado encontram-se discriminados no Quadro 6.

Destacam-se as classificações dos incêndios em Edificações Residenciais com 208 (34,15\%) ocorrências, em Edificações Comerciais com $131(21,51 \%)$ e em Veículos com 104 (17,08\%). Esses três tipos de incêndios representam um total de $72,73 \%$ dos sinistros periciados.

Na classificação Outros com 2,46\%, encontram-se relacionados: torre de transmissão de TV, embarcações (lancha, rebocador, barco de pesca), central telefônica, carrinho de milho e de cachorro-quente, elevador, canteiro de obras e containers.

Quadro 6 - Tipo de Incêndio.

\begin{tabular}{|l|c|c|c|c|c|c|c|c|c|c|c|c|}
\hline \multicolumn{1}{|c|}{ Tipo de Incêndio } & $\mathbf{1 9 8 9}$ & $\mathbf{1 9 9 0}$ & $\mathbf{1 9 9 1}$ & $\mathbf{1 9 9 2}$ & $\mathbf{1 9 9 3}$ & $\mathbf{1 9 9 4}$ & $\mathbf{1 9 9 5}$ & $\mathbf{1 9 9 6}$ & $\mathbf{1 9 9 7}$ & $\mathbf{1 9 9 8}$ & $\mathbf{1 9 9 9}$ & Total \\
\hline Depósito & 00 & 03 & 00 & 03 & 01 & 00 & 03 & 01 & 01 & 01 & 02 & $\mathbf{1 5}$ \\
\hline Edif. Comercial & 00 & 04 & 07 & 12 & 14 & 09 & 13 & 16 & 23 & 15 & 18 & $\mathbf{1 3 1}$ \\
\hline Edif. Educacional & 00 & 02 & 02 & 00 & 02 & 01 & 03 & 00 & 04 & 02 & 02 & $\mathbf{1 8}$ \\
\hline Edif. Hospedagem & 00 & 01 & 00 & 00 & 00 & 00 & 02 & 01 & 00 & 00 & 01 & $\mathbf{0 5}$ \\
\hline Edif. Industrial & 01 & 06 & 06 & 03 & 02 & 03 & 07 & 06 & 03 & 05 & 05 & $\mathbf{4 7}$ \\
\hline Edif. Mista & 00 & 00 & 00 & 00 & 00 & 00 & 00 & 01 & 01 & 02 & 01 & $\mathbf{0 5}$ \\
\hline Edif. Pública & 00 & 03 & 01 & 01 & 01 & 03 & 00 & 04 & 05 & 02 & 03 & $\mathbf{2 3}$ \\
\hline Edif. Residencial & 01 & 15 & 23 & 20 & 26 & 13 & 18 & 12 & 27 & 26 & 27 & $\mathbf{2 0 8}$ \\
\hline Local de Reunião & 00 & 02 & 00 & 00 & 00 & 00 & 02 & 01 & 01 & 00 & 01 & $\mathbf{0 7}$ \\
\hline Propriedade Rural & 00 & 00 & 00 & 01 & 00 & 00 & 00 & 01 & 00 & 00 & 00 & $\mathbf{0 2}$ \\
\hline Vegetação & 00 & 00 & 00 & 00 & 01 & 01 & 01 & 00 & 09 & 11 & 06 & $\mathbf{2 9}$ \\
\hline Veiculo & 00 & 03 & 08 & 06 & 07 & 12 & 08 & 09 & 14 & 14 & 23 & $\mathbf{1 0 4}$ \\
\hline Outros & 00 & 00 & 00 & 00 & 01 & 02 & 00 & 00 & 01 & 06 & 05 & $\mathbf{1 5}$ \\
\hline \multicolumn{1}{|c|}{ Total } & $\mathbf{0 2}$ & $\mathbf{3 9}$ & $\mathbf{4 7}$ & $\mathbf{4 6}$ & $\mathbf{5 5}$ & $\mathbf{4 4}$ & $\mathbf{5 7}$ & $\mathbf{5 2}$ & $\mathbf{8 9}$ & $\mathbf{8 4}$ & $\mathbf{9 4}$ & $\mathbf{6 0 9}$ \\
\hline
\end{tabular}

Fonte: Arquivos CBMES, organizado pelo autor.

Os dados coletados permitem, ainda, uma análise mais detalhada dos tipos de incêndios periciados, como por exemplo, a identificação das 


\section{Revista FLAMMAE}

Revista Científica do Corpo de Bombeiros Militar de Pernambuco

Seção 1 - Artigos Técnico Científicos

Artigo publicado no Vol.03 Nº7 - Edição de JUL a DEZ 2017 - ISSN 2359-4829

Versão on-line disponível em: http://www.revistaflammae.com.

características das edificações, o tipo de comércio envolvido, de veículo sinistrado, de edificação pública, etc. Neste texto será apresentada, a título de exemplificação, a análise da classificação que mais se destacou em número de ocorrências.

Os incêndios em Edificações Residenciais que representam 34,15\% das ocorrências revelam que: 94 (45,19\%) foram em casas de alvenaria de até 2 pavimentos; 63 (30,29\%) em apartamentos; 40 (19,23\%) em barracos de madeira; $6(2,88 \%)$ em casas de madeira e alvenaria e $5(2,4 \%)$ em outras subclassificações (obra, cabine de elevador, sauna, conjunto habitacional e orfanato).

\subsection{Causa do Incêndio}

A causa do incêndio, em sentido prático, pode ser entendida como a maneira ou o processo mediante o qual ocorreu a eclosão do incêndio. O Quadro 7 apresenta a descrição das causas adotada no período da análise. As causas decorrentes da intervenção humana direta ou indireta (ação pessoal) representam $41,54 \%$, as causas não apuradas $23,32 \%$, as derivadas dos fenômenos termoelétricos $19,21 \%$, as de origem acidental $15,60 \%$ e com apenas $0,33 \%$ as causas de origem natural (combustão espontânea e descarga elétrica atmosférica).

Quadro 7 - Causa do Incêndio.

\begin{tabular}{|l|c|c|c|c|c|c|c|c|c|c|c|c|}
\hline \multicolumn{1}{|c|}{ Causa do Incêndio } & $\mathbf{1 9 8 9}$ & $\mathbf{1 9 9 0}$ & $\mathbf{1 9 9 1}$ & $\mathbf{1 9 9 2}$ & $\mathbf{1 9 9 3}$ & $\mathbf{1 9 9 4}$ & $\mathbf{1 9 9 5}$ & $\mathbf{1 9 9 6}$ & $\mathbf{1 9 9 7}$ & $\mathbf{1 9 9 8}$ & $\mathbf{1 9 9 9}$ & Total \\
\hline Ação Pessoal & 00 & 00 & 00 & 00 & 00 & 03 & 03 & 04 & 16 & 16 & 29 & $\mathbf{7 1}$ \\
\hline Ação Pessoal Acidental & 00 & 05 & 04 & 03 & 01 & 00 & 02 & 00 & 04 & 01 & 00 & $\mathbf{2 0}$ \\
\hline Ação Pessoal Culposa & 00 & 00 & 00 & 01 & 00 & 02 & 02 & 01 & 00 & 00 & 00 & $\mathbf{0 6}$ \\
\hline Ação Pessoal Direta & 00 & 19 & 17 & 17 & 21 & 11 & 16 & 14 & 26 & 11 & 04 & 156 \\
\hline Fenômeno Termoelétrico & 01 & 08 & 11 & 10 & 13 & 10 & 09 & 09 & 11 & 18 & 17 & 117 \\
\hline Origem Acidental & 01 & 06 & 10 & 08 & 09 & 13 & 11 & 09 & 09 & 06 & 13 & $\mathbf{9 5}$ \\
\hline
\end{tabular}




\section{Revista FLAMMAE}

Revista Científica do Corpo de Bombeiros Militar de Pernambuco

Seção 1 - Artigos Técnico Científicos

Artigo publicado no Vol.03 N07 - Edição de JUL a DEZ 2017 - ISSN 2359-4829

Versão on-line disponível em: http://www.revistaflammae.com.

\begin{tabular}{|l|c|c|c|c|c|c|c|c|c|c|c|c|} 
Origem Natural & 00 & 00 & 01 & 00 & 00 & 00 & 01 & 00 & 00 & 00 & 00 & $\mathbf{0 2}$ \\
\hline Causa Não Apurada & 00 & 01 & 04 & 07 & 11 & 05 & 13 & 15 & 23 & 32 & 31 & $\mathbf{1 4 2}$ \\
\hline Total & $\mathbf{0 2}$ & $\mathbf{3 9}$ & $\mathbf{4 7}$ & $\mathbf{4 6}$ & $\mathbf{5 5}$ & $\mathbf{4 4}$ & $\mathbf{5 7}$ & $\mathbf{5 2}$ & $\mathbf{8 9}$ & $\mathbf{8 4}$ & $\mathbf{9 4}$ & $\mathbf{6 0 9}$ \\
\hline
\end{tabular}

Fonte: Arquivos CBMES, organizado pelo autor.

\subsection{Característica do Incêndio}

A característica do incêndio possibilita a identificação das

particularidades que contribuíram para a eclosão do incêndio, bem como dos fatores que levaram ao aumento da temperatura no foco inicial. Ela complementa a causa do incêndio com a finalidade de proporcionar um maior detalhamento e clareza possíveis.

O Quadro 8 apresenta as características do incêndio que foram utilizadas no período analisado. Observa-se a existência de algumas inconsistências e equívocos na utilização dessas características, notadamente, em virtude do elevado número adotado e da falta de um padrão de classificação $^{14}$.

Quadro 8 - Característica do Incêndio.

\begin{tabular}{|l|c|c|c|c|c|c|c|c|c|c|c|c|}
\hline \multicolumn{1}{|c|}{$\begin{array}{c}\text { Característica do } \\
\text { Incêndio }\end{array}$} & $\mathbf{1 9 8 9}$ & $\mathbf{1 9 9 0}$ & $\mathbf{1 9 9 1}$ & $\mathbf{1 9 9 2}$ & $\mathbf{1 9 9 3}$ & $\mathbf{1 9 9 4}$ & $\mathbf{1 9 9 5}$ & $\mathbf{1 9 9 6}$ & $\mathbf{1 9 9 7}$ & $\mathbf{1 9 9 8}$ & $\mathbf{1 9 9 9}$ & Total \\
\hline Acidental & 00 & 00 & 00 & 00 & 01 & 02 & 00 & 00 & 00 & 00 & 00 & $\mathbf{0 3}$ \\
\hline Arco Voltaico & 00 & 00 & 00 & 01 & 02 & 00 & 00 & 00 & 00 & 00 & 00 & $\mathbf{0 3}$ \\
\hline Caso fortuito & 00 & 01 & 00 & 00 & 00 & 00 & 00 & 00 & 00 & 00 & 00 & $\mathbf{0 1}$ \\
\hline Centelhamento & 00 & 00 & 00 & 00 & 02 & 00 & 01 & 02 & 02 & 01 & 00 & $\mathbf{0 8}$ \\
\hline Combustão espontânea & 00 & 00 & 01 & 00 & 01 & 01 & 00 & 00 & 00 & 00 & 00 & $\mathbf{0 3}$ \\
\hline Contato chama ou brasa & 00 & 02 & 05 & 00 & 03 & 08 & 16 & 16 & 32 & 25 & 31 & 138 \\
\hline $\begin{array}{l}\text { Contato superfície } \\
\text { aquecida }\end{array}$ & 00 & 00 & 00 & 00 & 00 & 01 & 01 & 00 & 00 & 01 & 03 & $\mathbf{0 6}$ \\
\hline Criminoso & 00 & 07 & 00 & 12 & 15 & 04 & 00 & 00 & 00 & 00 & 00 & $\mathbf{3 8}$ \\
\hline Curto-circuito & 01 & 07 & 08 & 06 & 07 & 10 & 04 & 08 & 09 & 15 & 15 & $\mathbf{9 0}$ \\
\hline $\begin{array}{l}\text { Defeito de } \\
\text { funcionamento }\end{array}$ & 00 & 00 & 00 & 00 & 00 & 00 & 00 & 03 & 05 & 02 & 01 & $\mathbf{1 1}$ \\
\hline \begin{tabular}{l} 
Descarga Elétrica \\
\hline
\end{tabular} & 00 & 00 & 00 & 00 & 00 & 00 & 01 & 00 & 00 & 00 & 00 & $\mathbf{0 1}$ \\
\hline
\end{tabular}

\footnotetext{
${ }^{14}$ A classificação utilizada para as causas e características dos incêndios foi sendo revisada e aprimorada ao longo dos anos com o objetivo de se obter uma padronização. Atualmente, a SPI adota somente 05 causas e 16 características para classificação das perícias de incêndios.
} 


\section{Revista FLAMMAE}

Revista Científica do Corpo de Bombeiros Militar de Pernambuco

Seção 1 - Artigos Técnico Científicos

Artigo publicado no Vol.03 Nº7 - Edição de JUL a DEZ 2017 - ISSN 2359-4829

Versão on-line disponível em: http://www.revistaflammae.com.

\begin{tabular}{|l|l|l|l|l|l|l|l|l|l|l|l|l|}
\hline Atmosférica & & & & & & & & & & & \\
\hline Disp. Adred. Preparado & 00 & 11 & 10 & 06 & 05 & 04 & 08 & 04 & 09 & 01 & 03 & $\mathbf{6 1}$ \\
\hline Explosão difusa & 00 & 00 & 00 & 00 & 00 & 00 & 01 & 00 & 00 & 00 & 00 & $\mathbf{0 1}$ \\
\hline Local Violado & 00 & 00 & 00 & 02 & 02 & 01 & 04 & 02 & 02 & 03 & 04 & $\mathbf{2 0}$ \\
\hline Negligência & 00 & 01 & 01 & 00 & 00 & 01 & 00 & 00 & 01 & 00 & 00 & $\mathbf{0 4}$ \\
\hline $\begin{array}{l}\text { Partículas em } \\
\text { suspensão }\end{array}$ & 00 & 00 & 00 & 00 & 00 & 00 & 00 & 00 & 01 & 00 & 00 & $\mathbf{0 1}$ \\
\hline Pseudo-explosão & 00 & 01 & 00 & 02 & 00 & 00 & 00 & 00 & 00 & 00 & 00 & $\mathbf{0 3}$ \\
\hline Sem característica & 00 & 03 & 13 & 07 & 10 & 03 & 05 & 04 & 03 & 04 & 00 & $\mathbf{5 2}$ \\
\hline Sobrecarga & 00 & 00 & 01 & 00 & 01 & 00 & 00 & 00 & 00 & 01 & 01 & $\mathbf{0 4}$ \\
\hline Superaquecimento & 00 & 01 & 01 & 03 & 01 & 00 & 04 & 01 & 01 & 02 & 04 & $\mathbf{1 8}$ \\
\hline Variação de tensão & 00 & 00 & 01 & 00 & 00 & 00 & 00 & 00 & 00 & 00 & 00 & $\mathbf{0 1}$ \\
\hline Vaz. de combustível & 00 & 00 & 02 & 05 & 02 & 06 & 02 & 01 & 00 & 01 & 00 & $\mathbf{1 9}$ \\
\hline Vaz. de gases inflam. & 00 & 00 & 00 & 01 & 00 & 00 & 00 & 00 & 00 & 00 & 00 & $\mathbf{0 1}$ \\
\hline Vazamento GLP & 01 & 05 & 04 & 01 & 03 & 02 & 03 & 01 & 03 & 01 & 05 & $\mathbf{2 9}$ \\
\hline Vestígios insuficientes & 00 & 00 & 00 & 00 & 00 & 01 & 07 & 10 & 21 & 27 & $\mathbf{2 7}$ & $\mathbf{9 3}$ \\
\hline \multicolumn{1}{|c|}{ Total } & $\mathbf{0 2}$ & $\mathbf{3 9}$ & $\mathbf{4 7}$ & $\mathbf{4 6}$ & $\mathbf{5 5}$ & $\mathbf{4 4}$ & $\mathbf{5 7}$ & $\mathbf{5 2}$ & $\mathbf{8 9}$ & $\mathbf{8 4}$ & $\mathbf{9 4}$ & $\mathbf{6 0 9}$ \\
\hline
\end{tabular}

Fonte: Arquivos CBMES, organizado pelo autor.

\subsection{Existência de Seguro Incêndio}

A existência ou não de Seguro Incêndio ${ }^{15}$ do patrimônio sinistrado está disposta no Quadro 9. Observa-se que 374 (61\%) deles não possuíam seguro e que no aprofundamento da análise dos dados verificou-se que dos 235 (39\%) que apresentaram o Seguro Incêndio, os que mais se destacaram foram: Edif. Comerciais - 67 (29\%); Edif. Residenciais - 57 (24\%); Edif. Industriais - 25 (15\%) e veículos - 47 (20\%).

Quadro 9 - Existência de Seguro de Incêndio.

\begin{tabular}{|c|c|c|c|c|c|c|c|c|c|c|c|c|}
\hline Seguro Incêndio & $\mathbf{1 9 8 9}$ & $\mathbf{1 9 9 0}$ & $\mathbf{1 9 9 1}$ & $\mathbf{1 9 9 2}$ & $\mathbf{1 9 9 3}$ & $\mathbf{1 9 9 4}$ & $\mathbf{1 9 9 5}$ & $\mathbf{1 9 9 6}$ & $\mathbf{1 9 9 7}$ & $\mathbf{1 9 9 8}$ & $\mathbf{1 9 9 9}$ & Total \\
\hline Sim & 02 & 13 & 18 & 18 & 16 & 22 & 22 & 32 & 32 & 30 & 30 & $\mathbf{2 3 5}$ \\
\hline Não & 00 & 26 & 29 & 28 & 39 & 22 & 35 & 20 & 57 & 54 & 64 & $\mathbf{3 7 4}$ \\
\hline Total & $\mathbf{0 2}$ & $\mathbf{3 9}$ & $\mathbf{4 7}$ & $\mathbf{4 6}$ & $\mathbf{5 5}$ & $\mathbf{4 4}$ & $\mathbf{5 7}$ & $\mathbf{5 2}$ & $\mathbf{8 9}$ & $\mathbf{8 4}$ & $\mathbf{9 4}$ & $\mathbf{6 0 9}$ \\
\hline
\end{tabular}

Fonte: Arquivos CBMES, organizado pelo autor.

\footnotetext{
${ }^{15}$ Maiores informações sobre Seguro Incêndio podem ser obtidas no site da Superintendência de Seguros Privados (SUSEP). http://www.susep.gov.br/menuatendimento/seguro_incendio_conteudo.
} 


\section{Revista FLAMMAE}

Revista Científica do Corpo de Bombeiros Militar de Pernambuco

Seção 1 - Artigos Técnico Científicos

Artigo publicado no Vol.03 Nº7 - Edição de JUL a DEZ 2017 - ISSN 2359-4829

Versão on-line disponível em: http://www.revistaflammae.com.

\subsection{Número de Vítimas}

No universo das 609 perícias de incêndios realizadas, encontrou-se o registro de vítimas fatais ou que apresentaram algum tipo de lesão em 43 situações, o que representa $7 \%$ do total.

O número total de vítimas não se encontra contabilizado bem como não sofreu, ao longo dos anos, uma análise mais detalhada e criteriosa por parte da SPI. O trabalho, de forma inédita, apresenta esse número por meio do Quadro 10 e, também, um detalhamento do sexo e da idade das vítimas fatais (menores ou adultos) no Quadro 11.

Quadro 10 - Número de Vítimas.

\begin{tabular}{|l|c|c|c|c|c|c|c|c|c|c|c|c|}
\hline \multicolumn{1}{|c|}{ Vítimas } & 1989 & 1990 & 1991 & 1992 & 1993 & 1994 & 1995 & 1996 & 1997 & 1998 & 1999 & Total \\
\hline Não Fatais & 00 & 00 & 02 & 04 & 01 & 33 & 07 & 15 & 06 & 02 & 03 & 73 \\
\hline Fatais & 00 & 01 & 05 & 01 & 02 & 04 & 04 & 06 & 04 & 04 & 05 & 36 \\
\hline
\end{tabular}

Fonte: Arquivos CBMES, organizado pelo autor.

Em relação ao número de vítimas, observa-se no ano de 1994 um total de 37 vítimas e no de 1996 um total de 21. Esses números são explicados em virtude dos incêndios ocorridos, respectivamente, no mercado da Vila Rubim e na obra de construção do Supermercado Roncetti, ambos no município de Vitória.

Nas vítimas não fatais, as que mais se destacaram foram as com lesões por queimaduras, seguidas das com escoriações e inalação de fumaça.

Quadro 11 - Sexo e Idade das Vítimas Fatais.

\begin{tabular}{|l|c|c|}
\hline \multirow{2}{*}{\multicolumn{1}{|c|}{ Vítimas Fatais }} & \multicolumn{2}{c|}{ Sexo } \\
\cline { 2 - 3 } & Masculino & Feminino \\
\hline Menores & 10 & 04 \\
\hline Adultos & 14 & 07 \\
\hline Não identificada & \multicolumn{2}{|c|}{01} \\
\hline
\end{tabular}

Fonte: Arquivos CBMES, organizado pelo autor. 


\section{Revista FLAMMAE}

Revista Científica do Corpo de Bombeiros Militar de Pernambuco

Seção 1 - Artigos Técnico Científicos

Artigo publicado no Vol.03 Nº7 - Edição de JUL a DEZ 2017 - ISSN 2359-4829

Versão on-line disponível em: http://www.revistaflammae.com.

Do total das 36 vítimas fatais, tem-se que $39 \%$ são menores, sendo $71 \%$ do sexo masculino e $29 \%$ do feminino. Já os adultos representam $58 \%$, com $67 \%$ de homens e $33 \%$ de mulheres. Uma vítima (3\%) consta no laudo pericial como não identificada.

No aspecto relacionado à existência de vítimas nos incêndios, observouse a carência de uma codificação nos laudos periciais que indicassem de forma clara e objetiva a sua tipologia bem como a falta de uma melhor qualificação das vítimas, constando essencialmente nome, idade e sexo.

\section{Considerações Finais}

O Serviço de Perícia de Incêndios e Explosões desenvolvido no Estado do Espírito Santo, a partir do ano de 1989, passou a ser estruturado e realizado, exclusivamente, pelo Corpo de Bombeiros Militar.

A pesquisa mostrou que de uma forma geral o Serviço de Perícia de Incêndios e Explosões no período de 1989 a 1999 cumpriu bem as finalidades de elucidação das causas dos incêndios, auxílio às questões de justiça e respaldo as companhias de seguro. Entretanto, não apresentou dados que evidenciassem a retroalimentação do Ciclo Operacional de Bombeiros.

Durante o desenvolvimento da pesquisa verificou-se que a estrutura atual do serviço apresenta algumas carências para atender, notadamente, a sua alta demanda, as necessidades de exames laboratoriais, e, sobretudo, a capacitação permanente do pessoal envolvido (peritos e auxiliares) na sua realização.

Portanto, sendo a realização de perícias de incêndios e explosões em local de sinistros uma atribuição constitucional do CBMES, torna-se fundamental e necessário que a Corporação valorize esse Serviço, 


\section{Revista FLAMMAE}

Revista Científica do Corpo de Bombeiros Militar de Pernambuco

Seção 1 - Artigos Técnico Científicos

Artigo publicado no Vol.03 Nº7 - Edição de JUL a DEZ 2017 - ISSN 2359-4829

Versão on-line disponível em: http://www.revistaflammae.com.

modernizando a sua estrutura, fortalecendo os aspectos doutrinários e aprimorando os mecanismos internos de controle para que ele realmente possa cumprir fielmente todas as finalidades que se destina.

Durante a pesquisa evidenciou-se, também, a necessidade da Corporação melhorar a conservação e o armazenamento dos laudos periciais e dos arquivos fotográficos, pois além dos aspectos legais envolvidos, eles registram o desenvolvimento histórico do serviço, constituindo-se em uma importante e valiosa fonte para pesquisas futuras.

Por fim, registro que todos os dados levantados para essa pesquisa (organizados em planilhas do programa Microsoft Excel) serão disponibilizados no site www.bombeiros.es.gov.br, na esperança de que eles sirvam para futuras consultas e incentivem a continuidade e o aprofundamento desse trabalho.

\section{Referências}

ARAGÃO, Ranvier Feitosa. Incêndios e explosivos: uma introdução à engenharia forense. Campinas, SP: Millennium Editora, 2010.

BRASIL. Constituição (1988). Constituição da República Federativa do Brasil. Brasília, DF: Senado Federal, 1999.

Decreto-Lei, № 2.848, de 07 de dezembro de 1940. Código Penal. Diário Oficial da República Federativa do Brasil, Rio de Janeiro, 31 dez. 1940. 


\section{Revista FLAMMAE}

Revista Científica do Corpo de Bombeiros Militar de Pernambuco

Seção 1 - Artigos Técnico Científicos

Artigo publicado no Vol.03 N07 - Edição de JUL a DEZ 2017 - ISSN 2359-4829

Versão on-line disponível em: http://www.revistaflammae.com.

. Decreto-Lei, № 3.689, de 03 de outubro de 1941. Código de Processo

Penal. Diário Oficial da República Federativa do Brasil, Rio de Janeiro, 13 out. 1941.

ESPÍRITO SANTO (Estado). Constituição (1989). Constituição do Estado do Espírito Santo. Vitória: Assembleia Legislativa, 2011.

. Constituição (1967). Constituição do Estado do Espírito

Santo. 2. ed. Vitória: Assembleia Legislativa, 1984.

. Lei Complementar $n^{\circ} 101$, de 22 de setembro de 1997. Dispõe sobre a organização básica do Corpo de Bombeiros Militar do Estado do Espírito Santo e dá outras providências. Diário Oficial do Estado do Espírito Santo, Vitória, 23 set. 1997.

. Lei $n^{\circ} 3.044$, de 31 de dezembro de 1975. Dispõe sobre a organização básica da Polícia Militar do Estado do Espírito Santo e dá outras providências. Diário Oficial do Estado do Espírito Santo, Vitória, 31 dez. 1975.

. Decreto $n^{\circ} 1.462$, de 10 de outubro de 1980. Modifica e estrutura básica da Polícia Militar. Diário Oficial do Estado do Espírito Santo, Vitória, 11 out. 1980.

. Decreto ${ }^{\circ} 2.089-\mathrm{N}$, de 10 de julho de 1985. Classifica os cargos do Quadro de Pessoal as Polícia Civil, específica as suas atribuições e dá outras providencias. Diário Oficial do Estado do Espírito Santo, Vitória, 11 jul. 1985. 


\section{Revista FLAMMAE}

Revista Científica do Corpo de Bombeiros Militar de Pernambuco

Seção 1 - Artigos Técnico Científicos

Artigo publicado no Vol.03 N07 - Edição de JUL a DEZ 2017 - ISSN 2359-4829

Versão on-line disponível em: http://www.revistaflammae.com.

LOIOLA, Gelson. A evolução histórica do Corpo de Bombeiros Militar do

Estado do Espírito Santo. Vitória: Canela Verde, 2010.

LOPES DE SÁ, Antônio. Perícia Contábil. 10 ed. São Paulo: Atlas, 2011.

OLIVEIRA, Robson Araújo de. Perícia e Pesquisa: Abordagem prática a respeito da realidade atual. 2009. 226 f. Monografia (Especialização em Perícia de Incêndio e Produção de Provas Judiciais) - Centro Universitário UNIEURO, Brasília, 2009.

SANTOS, José Luiz dos; GOMES, José Mário M.; SCHMIDT, Paulo.

Fundamentos de perícia contábil. Vol. 18. São Paulo: Atlas, 2006.

SARTE, Anderson Medeiros. Perícia de incêndio: uma abordagem sobre a coleta de amostras sólidas e líquidas em edificações sinistradas pelo fogo. 2009. 114 f. Monografia (Graduação em Tecnologia em Gestão de Emergências) - Centro de Educação de São José, Universidade do Vale do Itajaí, São José, 2009.

VASCONCELOS, Leila Miranda; FRABI, Paulo José; CASTRO, Fábio Rogério de. Perícia contábil: uma análise sobre a formação acadêmica do perito contador. In: ENCONTRO DE PRODUÇÃO CIENTÍFICA E TECNOLÓGICA, 6. 2011, Campo Mourão, PR. Anais... Campo Mourão: Faculdade Estadual de Ciências e Letras de Campo Mourão/Núcleo de Pesquisa Multidisciplinar, 2011.

UNIVERSIDADE FEDERAL DO ESPÍRITO SANTO. Biblioteca Central. Guia para normalização de referências: NBR 6023:2002. 2. ed. Vitória, 2002.

ZARZUELA, José Lopes; ARAGÃO, Ranvier Feitosa. Química legal e incêndios: tratado de perícias criminalísticas. Porto Alegre: Sagra Luzzatto, 1999. 